New Hybr i d- type Squar ami de- Fused Ami no Al cohol Or ganocat al yst for Enant i osel ect i ve Dom no $M$ chael Addi ti on/Cycl i zat i on React i on of Oxoi ndol i nes wi th $\mathrm{Cycl}$ i c 1, 3- Di ket ones

\begin{tabular}{|l|l|}
\hline 著者 & $\begin{array}{l}\text { CHENAPURAM Nadhu, ONOLABI I si aka Al ade, SEK } \\
\text { Chi gusa, OKUYAMA Yuko, KWON Eunsang, UAA } \\
\text { Koj i , TOK WA M chi o, TAKESH TA M t suhi ro, } \\
\text { NAKANO H r ot o }\end{array}$ \\
\hline $\begin{array}{l}\text { j our nal or } \\
\text { publ i cat i on t i t l e }\end{array}$ & ACS OMEGA \\
\hline vol une & 3 \\
\hline number & 9 \\
\hline page r ange & $11718-11726$ \\
\hline year & 2018 \\
\hline URL & ht t p: //hdl . handl e. net /10258/00010362 \\
\hline
\end{tabular}




\title{
New Hybrid-type Squaramide-Fused Amino Alcohol Organocatalyst for Enantioselective Domino Michael Addition/Cyclization Reaction of Oxoindolines with Cyclic 1,3-Diketones
}

\author{
Madhu Chennapuram, ${ }^{\dagger}$ Isiaka Alade Owolabi, ${ }^{\dagger}$ Chigusa Seki, ${ }^{\dagger}$ Yuko Okuyama, ${ }^{\ddagger}$ Eunsang Kwon, ${ }^{\S}$ \\ Koji Uwai, ${ }^{\dagger}$ Michio Tokiwa," Mitsuhiro Takeshita," and Hiroto Nakano*, ${ }^{\dagger}$
}

\begin{abstract}
${ }^{\dagger}$ Division of Sustainable and Environmental Engineering, Graduate School of Engineering, Muroran Institute of Technology, 27-1 Mizumoto-cho, Muroran 050-8585, Japan

${ }^{\ddagger}$ Tohoku Medical and Pharmaceutical University, 4-4-1 Komatsushima, Aoba-ku, Sendai 981-8558, Japan

${ }^{\S}$ Research and Analytical Centre for Giant Molecules, Graduate School of Sciences, Tohoku University, 6-3 Aoba, Aramaki, Aoba-ku, Sendai 980-8578, Japan

"Tokiwakai Group, 62 Numajiri, Tsuduri-chou Uchigo, Iwaki 973-8053, Japan
\end{abstract}

Supporting Information

ABSTRACT: The new hybrid-type squaramide-fused amino alcohol containing both a Brønsted basic site and hydrogenbonding sites in the molecule showed a high catalytic activity as an organocatalyst in the enantioselective domino Michael addition/cyclization reaction of oxoindolines with cyclic 1,3diketones to afford the chiral spiro-conjugated oxindoles featuring 2-aminopyrans fusing with carbo-heterocyclic ring systems with excellent chemical yields (up to 98\%) and enantioselectivities (up to 95\% ee). The obtained chiral spiroconjugated 2-aminopyrans bearing quaternary stereogenic carbon center could be used as synthetic precursors for several natural products that have a broad spectrum of fascinating biological activities.

\section{INTRODUCTION}

In the enormously progressing field of synthetic organic chemistry, the construction of carbon-carbon and a carbonheteroatom bond is an important strategy for the construction of complex organic molecules. ${ }^{1}$ The domino approach is one of the major tools to construct biologically important complex molecules and its precursors from simple substrates in one-pot fashion, which is ecologically and economically benign. ${ }^{2}$ The enantioselective domino Michael addition/cyclization reaction of oxoindoline with cyclic or acyclic 1,3-diketones affords the synthetically valuable chiral carbo-heterocyclic spiro-oxindoles A, that are synthetic intermediates for preparing many biologically active molecules, such as rychnophylline (tetracyclic oxindole alkaloid), formosanine (pentacyclic oxindole alkaloid), elacomine (hemiterpene oxindole alkaloid), and pyranopyrazole (synthetic dye-stuff), in the field of synthetic organic chemistry (Scheme 1). ${ }^{3-6}$

However, the methodology of preparation of vital spirooxindole A, incorporating a chiral spiro-conjugated aminopyran framework at C-3 position of oxindoles, is still limited. Recently, Yuan and his co-workers ${ }^{7}$ reported the first enantioselective domino Michael addition/cyclization reaction of oxoindolines B with acyclic 1,3-diketones $\mathbf{C}$ using cupreine (CPN) organocatalyst to afford chiral spiro-conjugated oxindoles with 2-aminopyrans framework $\mathbf{E}$ in both excellent chemical yield (up to 99\%) and enantioselectivities (up to $97 \%$ ee) (Scheme 2). However, this CPN catalyst did not work efficiently for the reaction of cyclic 1,3-diketones $\mathbf{D}$ with oxoindolines to afford the chiral spiro-conjugated oxindoles $\mathbf{F}$ with 2-aminopyrans fusing carbo-heterocyclic ring systems at C-4 and C-5 positions in terms of enantioselectivity (up to $8 \%$ ee), in spite of the obtained products being useful for the synthesis of biologically important molecules from the point of view of drug discovery.

Most recently, we developed the new hybrid-type squaramide-fused amino alcohol (SFAA) organocatalysts and the catalyst was successfully employed in enantioselective nitroaldol and Diels-Alder reactions to afford the corresponding synthetically important chiral products in satisfactory chemical yields and enantioselectivities. ${ }^{9}$ On the basis of these reasons, we planned to apply our newly developed SFAA organocatalyst for enantioselective domino Michael addition/cyclization reaction of oxoindolines with cyclic 1,3-diketones, affording the chiral spiro-conjugated oxindoles with 2-aminopyrans fusing with carbo-heterocyclic ring systems.

The SFAA organocatalyst possesses multiple functional sites, such as diamino groups on squaramide part for hydrogenbonding with the substrate, tertiary amino group acting as a

Received: June 7, 2018

Accepted: September 3, 2018

Published: September 24, 2018 
Scheme 1. Biological Significance of Chiral Oxindole Incorporating Spiro-conjugated Amino Framework

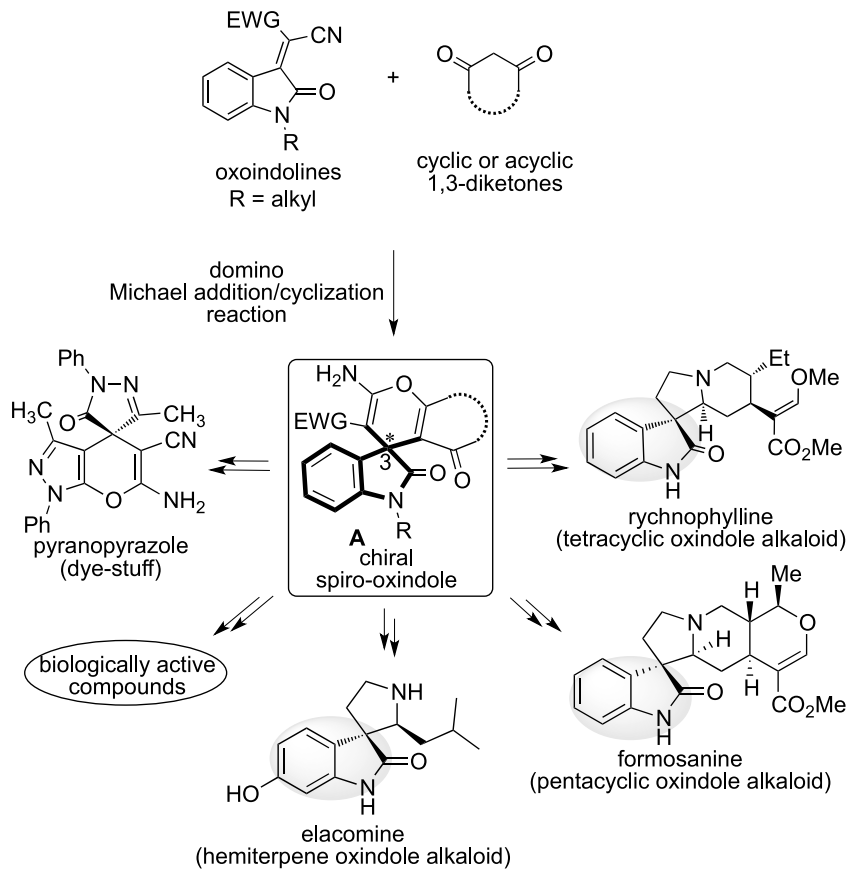

Scheme 2. Cupreine-Catalyzed Enantioselective Domino Michael Addition/Cyclization

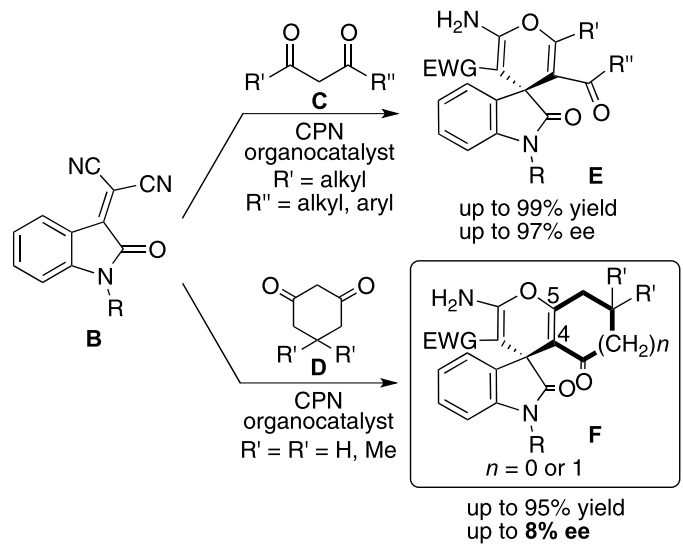

Brønsted base, and phenyl groups acting as steric influence site for recognition by substrates (Scheme 3 ). The enantioselective domino Michael addition/cyclization reaction of oxoindolines with cyclic 1,3-diketones using SFAA catalyst might proceed via transition state $\mathbf{X}$, in which the hydroxy functional group on catalysts might participate in hydrogen-bonding interaction with squaramide carbonyl oxygen atom. Additionally, the enolate of cyclic 1,3-diketones might be fixed through hydrogen-bonding interactions with the ammonium site at the side chain of the catalyst part. Furthermore, two cyano groups of oxoindoline might be fixed through two hydrogenbonding interactions with two amino hydrogen atoms of the squaramide unit of the catalyst. The activated enolate generated from 1,3-diketones might attack stereoselectively on electron-deficient olefin on oxoindolines from the less sterically hindered site of the fixed oxoindoline to afford the chiral Michael adduct, and subsequent intramolecular cyclization/tautomerization might afford the corresponding chiral spiro-conjugated oxindoles with 2-aminopyrans fusing carbo-
Scheme 3. Concept of Domino Michael Addition/ Cyclization Reaction of Oxoindolines with Cyclic 1,3Diketones Using SFAA Organocatalyst

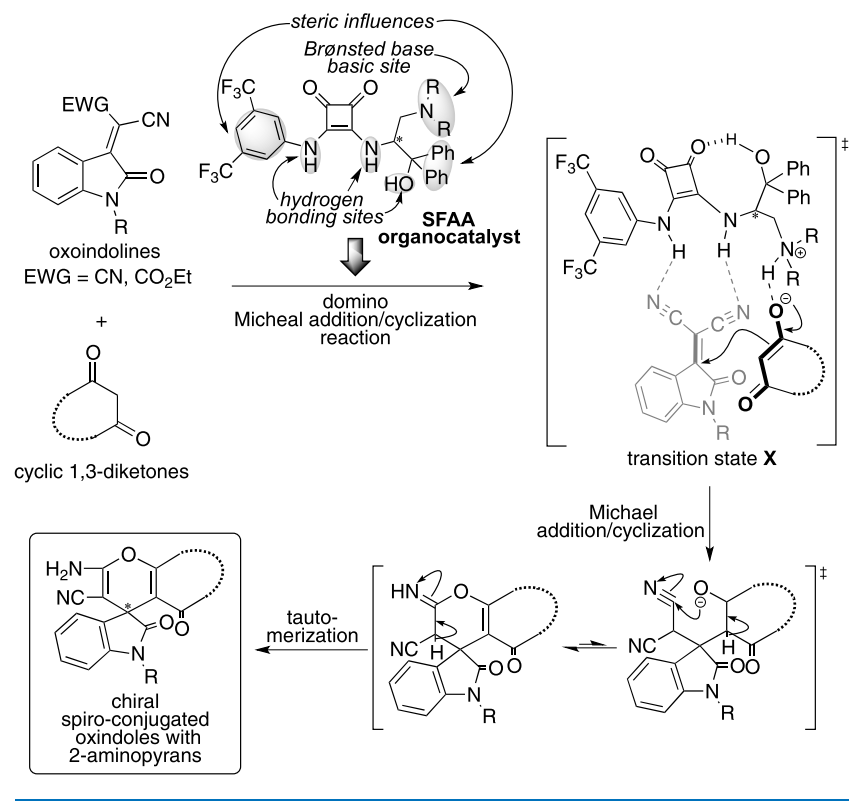

heterocyclic ring systems in satisfactory chemical yield and enantioselectivity.

We report herein that the first domino Michael addition/ cyclization reaction of cyclic 1,3-diketones with oxoindolines using SFAA catalyst afforded the chiral spiro-conjugated oxindoles with 2-aminopyrans fusing carbo-heterocyclic ring systems in excellent chemical yields (up to 98\%) and with excellent enantioselectivities (up to $95 \%$ ee), although cupreine catalyst only afforded the spiro products in poor enantioselectivities (up to $8 \%$ ee) when cyclic 1,3-diketones were used.

\section{RESULTS AND DISCUSSION}

The catalysts $3 \mathbf{a}-\mathbf{e}$ with different sizes of heterocyclic ring systems on the amino alcohol part were easily prepared according to our previously reported method using the condensation of squaramide with amino alcohols. ${ }^{9}$ At the outset of the study, the domino Michael addition/cyclization reaction of oxoindolines $\mathbf{1} \mathbf{a}, \mathbf{b}$ with dimedone $\mathbf{2} \mathbf{a}$ was tried using SFAA catalysts $3 \mathrm{a}-\mathbf{e}(10 \mathrm{~mol} \%)$ in toluene or tetrahydrofuran (THF). The results are summarized in Table 1. First, the reaction using catalyst $3 \mathrm{a}(10 \mathrm{~mol} \%)$ was conducted with oxoindoline $\mathbf{1 a}$ and dimedone $\mathbf{2 a}$ in toluene at room temperature (RT) for $24 \mathrm{~h}$ but only a trace amount of desired spiro-pyran 4a was obtained (entry 1). Next, the reactions using catalysts $\mathbf{3 b}$ and $\mathbf{3 c}$ were also carried out, respectively, and the corresponding $\mathbf{4 a}$ was afforded in good chemical yields (3b: $82 \%, 3$ c: $90 \%$ ) but with poor enantioselectivities (3b: 7\% ee, $3 \mathrm{c}$ : $9 \%$ ee) (entries 2 and 3). Furthermore, the reaction using catalyst $\mathbf{3 b}$ was also conducted in THF (polar aprotic solvent) but the reaction only afforded $\mathbf{4 a}$ as racemate, although good chemical yield (90\%) was obtained (entry 4). On the basis of these results, we assumed that the use of sterically bulkier oxoindolines might be effective to control the enantioselectivity in this reaction.

The reaction of bulkier $N$-Bn-oxoindoline $\mathbf{1} \mathbf{b}$ with $\mathbf{2 a}$ using catalyst $\mathbf{3 b}$ was carried out in toluene. Unfortunately, this reaction also afforded the racemic $\mathbf{4 b}$, although the chemical 
Table 1. Optimization of the Michael Addition/Cyclization Reaction of Oxoindolines 1a,b with Dimedone 2a Using Catalysts $3 a-e, G$, and $H$
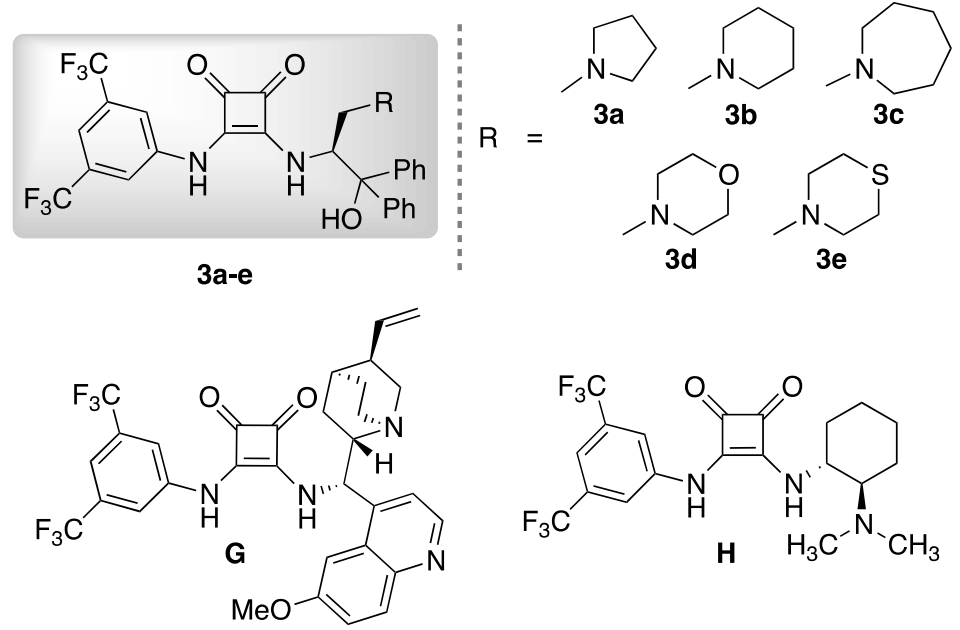<smiles>CN(C)C1CCCCC1[NH2+]c1c(Nc2cc(C(F)(F)F)cc(C(F)(F)F)c2)c(=O)c1=O</smiles>

quinine squaramide catalyst

diamine squaramide catalyst<smiles>[R]N1C(=O)C(=C(C#N)C#N)c2ccccc21</smiles><smiles>CC1(C)CC(=O)CC(=O)C1</smiles>

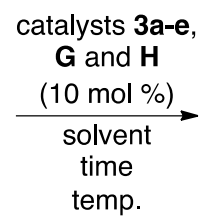<smiles></smiles>

1a: $\mathrm{R}=\mathrm{H}$ $1 \mathrm{~b}: \mathrm{R}=\mathrm{Bn}$

$2 a$

\section{solvent \\ toluene \\ toluene \\ toluene \\ THF \\ toluene \\ THF \\ THF \\ THF \\ THF \\ THF \\ THF \\ THF}

$\begin{array}{cr}\text { time (h) } & \text { temp } \\ 24 & \mathrm{R}^{\prime} \\ 24 & \mathrm{R}^{\prime} \\ 24 & \mathrm{R}^{\prime} \\ 24 & 0 \\ 24 & \mathrm{R}^{\prime} \\ 48 & 0 \\ 48 & 0 \\ 48 & 0 \\ 48 & 0 \\ 48 & 0 \\ 48 & 0 \\ 48 & 0\end{array}$

$\begin{array}{lcc}\text { p }\left({ }^{\circ} \mathrm{C}\right) & \text { yield }(\%)^{b} & \text { ee }(\%)^{c} \\ \text { RT } & \text { trace } & \\ \text { RT } & 82 & 9 \\ \text { RT } & 90 & 7 \\ 0 & 90 & \mathrm{rac} \\ \text { RT } & 95 & \mathrm{rac} \\ 0 & 89 & 77 \\ 0 & 92 & 79 \\ 0 & 95 & 75 \\ 0 & 96 & 10 \\ 0 & 97 & \mathrm{rac} \\ 0 & 86 & 70 \\ 0 & 91 & 24\end{array}$

${ }^{a}$ The reactions were carried out with $\mathbf{1 a}, \mathbf{b}(0.1 \mathrm{mmol})$ and $\mathbf{2 a}(0.1 \mathrm{mmol})$ using catalysts $\mathbf{3 a}-\mathbf{e}, \mathbf{G}$ and $\mathbf{H}(10 \mathrm{~mol} \%)$ in above-mentioned solvents $(1.0 \mathrm{~mL}) .{ }^{b}$ Isolated yields. ${ }^{c}$ The ee were determined by chiral high-performance liquid chromatography (HPLC) using CHIRALCEL OD-H or CHIRALPAK AD-H columns.

yield was excellent (95\%) (entry 5). Moreover, the same reaction using $\mathbf{3 b}$ was examined in THF. Surprisingly, the enantioselectivity was greatly increased to $77 \%$ ee with good chemical yield (89\%) (entry 6). The reaction using 3a was also carried out in the same reaction conditions as those of $3 \mathbf{b}$. Similarly, the catalyst 3 a showed good catalytic activity to afford $\mathbf{4 b}$ in excellent chemical yield (92\%) and with good enantioselectivity (79\% ee) (entry 7 ). Furthermore, the use of catalyst $3 \mathrm{c}$ was also examined to afford the chiral $\mathbf{4 a}$ in excellent chemical yield (95\%) with good enantioselectivity ( $75 \%$ ee) (entry 8 ). Encouraged by the results using THF as a solvent, the reactions using catalysts $\mathbf{3 d}$ and $3 \mathbf{e}$ were also carried out in THF, respectively. However, the reaction afforded $\mathbf{4 b}$ in poor enantioselectivities (entries 9 and 10). Furthermore, this reaction of $\mathbf{1} \mathbf{b}$ with $\mathbf{2 a}$ using well-known quinine $\mathbf{G}$ and diamine squaramide $\mathbf{H}$ catalysts was examined (entries 11 and 12), respectively. As a result, catalyst G afforded $\mathbf{4 b}$ in both good chemical yield (86\%) and enantioselectivity $(70 \%$ ee) (entry 11$)$. On the other hand, catalyst $\mathbf{H}$ provided $\mathbf{4} \mathbf{b}$ in excellent chemical yield (91\%) but with poor enantioselectivities ( $24 \%$ ee) (entry 12 ). By these results, it was found that catalyst 3 a possessing pyrrolidine ring was the most effective in this reaction of $\mathbf{1} \mathbf{b}$ with $\mathbf{2} \mathbf{a}$.

To optimize the reaction conditions using superior catalyst 3a, we next examined the molar ratio of catalyst, the effect of solvents, and the reaction temperatures (Table 2, entries 115). An increase in the catalyst loading amount from 10 to 20 mol \% 3a resulted in a remarkable increase in chemical yield (96\%) and unpredicted decrease in enantioselectivity (7\% ee), although the reason was not clear (entry 1). On the other hand, the catalytic loading of $5 \mathrm{~mol} \%$ 3a brought about both increase of chemical yield (95\%) and enantioselectivity (83\%) (entry 2). Furthermore, the reaction was also tried in the presence of $2 \mathrm{~mol} \% 3 \mathbf{a}$ to afford the chiral product $4 \mathbf{b}$ in 
Table 2. Optimization of Reaction Conditions for the Domino Michael Addition/Cyclization Reaction Using Catalyst 3a

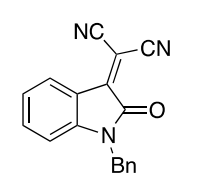

1b

$\begin{array}{rc}\text { entry }^{a} & \begin{array}{c}\text { catalyst 3a } \\ (\text { mol \%) }\end{array} \\ 1 & 20 \\ 2 & 5 \\ 3 & 2 \\ 4 & 5 \\ 5 & 5 \\ 6 & 5 \\ 7 & 5 \\ 8 & 5 \\ 9^{d} & 5 \\ 10 & 5 \\ 11 & 5 \\ 12 & 5 \\ 13 & 5 \\ 14 & 5 \\ 15 & 5\end{array}$

$\begin{array}{cl}\text { solvent } & \begin{array}{l}\text { temp } \\ \left({ }^{\circ} \mathrm{C}\right)\end{array} \\ \text { THF } & 0 \\ \text { THF } & 0 \\ \text { THF } & 0 \\ \text { THF } & -10 \\ \text { THF } & -50 \\ \text { THF } & -80 \\ \text { Et }{ }_{2} \mathrm{O} & 0 \\ \text { DIPE } & 0 \\ \text { 1,4-dioxane } & \mathrm{RT} \\ \text { DCM } & 0 \\ \text { chloroform } & 0 \\ \text { DCE } & 0 \\ \text { DMF } & 0 \\ \text { DMA } & 0 \\ \text { MeOH } & 0\end{array}$

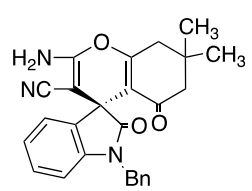

$4 b$
The reactions were carried out with $\mathbf{1 b}(0.1 \mathrm{mmol})$ and $\mathbf{2 a}(0.1$ $\mathrm{mmol}$ ) using catalyst $3 \mathbf{a}$ in above-mentioned solvents $(0.1 \mathrm{~mL})$. ${ }^{b}$ Isolated yields. ${ }^{c}$ The ee were determined by chiral HPLC using CHIRALPAK AD-H column. ${ }^{d}$ The reaction was conducted at room temperature.

excellent chemical yield (92\%) with good enantioselectivity ( $81 \%$ ee) (entry 3 ). To further improve the enantioselectivity of $\mathbf{4 b}$, we also examined the catalytic activity of $\mathbf{3 a}$ at low temperatures $\left(-10\right.$ to $\left.-80{ }^{\circ} \mathrm{C}\right)$. Under these conditions, good enantioselectivities $(73-81 \%$ ee) were obtained with fairly good chemical yields (87-92\%) (entries 4-6). Next, we examined the effects of different ethereal solvents, such as diethyl ether $\left(\mathrm{Et}_{2} \mathrm{O}\right)$, diisopropyl ether (DIPE), and 1,4dioxane in this reaction using $5 \mathrm{~mol} \% 3 \mathrm{a}$. From the results, the enantioselectivities widely decreased in these solvents, although the chemical yields were good to excellent (entries 7-9). Moreover, the reactions were carried out in chlorinated solvents, such as dichloromethane (DCM), chloroform, and 1,2-dichloroethane (DCE). However, the chiral $4 \mathrm{~b}$ was obtained in good-to-excellent chemical yield (89-96\%) and only poor-to-moderate enantioselectivities (7-51\% ee) (entries 10-12). Similarly, the uses of highly polar solvents, such as dimethylformamide (DMF), dimethylacetamide (DMA), and $\mathrm{MeOH}$, also afforded racemic $\mathbf{4} \mathbf{b}$ with good chemical yields (89-92\%) (entries 13-15). From these results, it turned out that the use of $5 \mathrm{~mol} \% 3 \mathrm{a}$ in THF at $0{ }^{\circ} \mathrm{C}$ for $48 \mathrm{~h}$ was the optimal condition for this reaction. In general, enantiomeric excess in asymmetric reactions strongly depends on the solvent effect. It might be reasoned that THF coordinates in the reaction system include both the catalyst and substrates for forming a better transition state to afford satisfactory optical purity for this reaction.

Under the optimal reaction conditions, the reactions using a wide range of oxoindolines $\mathbf{1} \mathbf{c}-\mathbf{m}$ with cyclic 1,3-diketones $\mathbf{2 a}-\mathbf{c}$ were examined in the domino Michael addition/ cyclization reaction in the presence of superior catalyst $\mathbf{3 a}$ to afford the corresponding chiral spiro-conjugated 2-aminopyrans $4 \mathbf{c}-\mathbf{r}$. The results are summarized in Scheme 4. The reaction of $\mathrm{N}$-para-methoxybenzyl-oxoindoline 1c with dimedone $\mathbf{2 a}$ afforded the corresponding spiro-pyran $4 \mathrm{c}$ in both good chemical yield ( $89 \%)$ and enantioselectivity ( $81 \%$ ee). However, the use of electron-deficient $N$-Boc-oxoindoline 1d gave $\mathbf{4 d}$ in good chemical yield $(72 \%)$ but with poor enantioselectivity ( $5 \%$ ee). This failure might be due to the electronic characteristics of $\mathbf{1 d}$, although the reason is not clear. The best result $(92,95 \%$ ee $)$ was obtained in the reaction of $\mathrm{N}$-methyl-oxoindoline $1 \mathrm{e}$ with $\mathbf{2 a}$. The absolute configuration of the obtained chiral spiro-pyran (3S)-4e was determined by X-ray analysis (see the Supporting Information). The reactions of $N$-ethyl and $N$-methoxymethyl oxoindolines 1f,g with $\mathbf{2 a}$ afforded the corresponding chiral products $\mathbf{4 f}$ and $\mathbf{4 g}$ in good-to-excellent chemical yields (4f: 87\%, 4g: 95\%) and with moderate-to-good enantioselectivities (4f: $84 \%$ ee, $4 \mathrm{~g}: 75 \%$ ee), respectively. Furthermore, the reactions were also conducted using $N$-acetyl oxoindoline $\mathbf{1 h}$ or silyl-protected $N$-tert-butyldimethylsilyl oxoindoline $\mathbf{1 i}$ with $\mathbf{2 a}$, to afford the chiral spiro-pyrans $\mathbf{4 h , i}$ in moderate-to-good chemical yields (4h: $90 \%, 4 \mathbf{i}: 72 \%$ ) and moderate-to-poor enantioselectivities (4h: $80 \%$ ee, $4 \mathbf{i}$ : $9 \%$ ee). The use of bulkier naphthyl-(2-methylene)-oxoindoline $\mathbf{1 j}$ also afforded the chiral $4 \mathbf{j}$ in good chemical yield (81\%) with enantioselectivity $(71 \%$ ee). Additionally, the domino Michael addition/cyclization reaction using $N$-methyl-oxoindoline le was extended to the reaction with other cyclic 1,3-diketones, such as 1,3-cyclohexadione $\mathbf{2 b}$ and 1,3-cyclopentadione $\mathbf{2}$ c, using catalyst $\mathbf{3 a}$. The reaction of $\mathbf{1 e}$ with $\mathbf{2} \mathbf{b}$ afforded the desired product $\mathbf{4 k}$ in both good chemical yield and enantioselectivity (4k: 90\%, 76\% ee). On the other hand, the reaction between $1 \mathrm{e}$ and $2 \mathrm{c}$ afforded product 41 in good chemical yield but with poor enantioselectivity (41: 90\%, 12\% ee). The use of 5-fluoro- $\mathrm{N}$ methyl-oxoindoline $\mathbf{1 k}$ also afforded the corresponding product $4 \mathrm{~m}$ in both good chemical yield and enantioselectivity (4m: $72 \%, 71 \%$ ee).

Next, the reaction of 5-bromo- $N$-methyl-oxoindoline $\mathbf{1 1}$ with 2a was also carried out and the product $4 \mathrm{n}$ was obtained in excellent chemical yield with racemate, although the reason is not clear. Similarly, the reaction of $1 \mathbf{m}$ with $2 \mathrm{a}$ also afforded the anticipated product 4o obtained as racemate but with good chemical yield (4o: 81\%). We also examined the reaction of $N$ methyl-oxoindoline 1e with acyclic 1,3-diketones $\mathbf{2 d - f}$ using catalyst $3 a$. However, the desired products $4 p-r$ were obtained as racemates, proceeded with a good chemical yield (72$81 \%$ ), respectively. The formation of racemates $4 p-r$ may be for the unfavored interaction of substrates $\mathbf{2 d}-\mathbf{f}$ with catalyst $3 \mathrm{a}$, respectively, although the reason is not clear. These results of the reactions of acyclic 1,3 -diketones $4 p-r$ are in contrast to the previously reported results. ${ }^{8}$ To demonstrate the practical utility of catalyst 3a, the domino Michael addition/cyclization reaction between oxoindoline $1 \mathbf{e}$ and $\mathbf{2 a}$ was conducted on a gram scale $(1 \mathrm{e}: 1 \mathrm{~g})$ using optimized reaction conditions (3a: 5 mol \%, THF, $0{ }^{\circ} \mathrm{C}, 48 \mathrm{~h}$ ) and the corresponding product $4 \mathrm{e}$ was obtained in excellent chemical yield (96\%). Unfortunately, the enantioselectivity of $4 \mathrm{e}$ was $35 \%$ ee (see the Supporting Information). This result indicated that a detailed examination of the reaction conditions should be necessary (on a small scale) for obtaining satisfactory optical purity of $4 \mathbf{e}$ for use on the gram scale.

On the basis of the observed enantiopurity (95\% ee) of chiral spiro-pyran $4 \mathrm{e}$ that was obtained from the reaction of $1 \mathrm{e}$ 
Scheme 4. Substrate Scope for the Domino Michael Addition/Cyclization Reaction Using Catalyst 3a

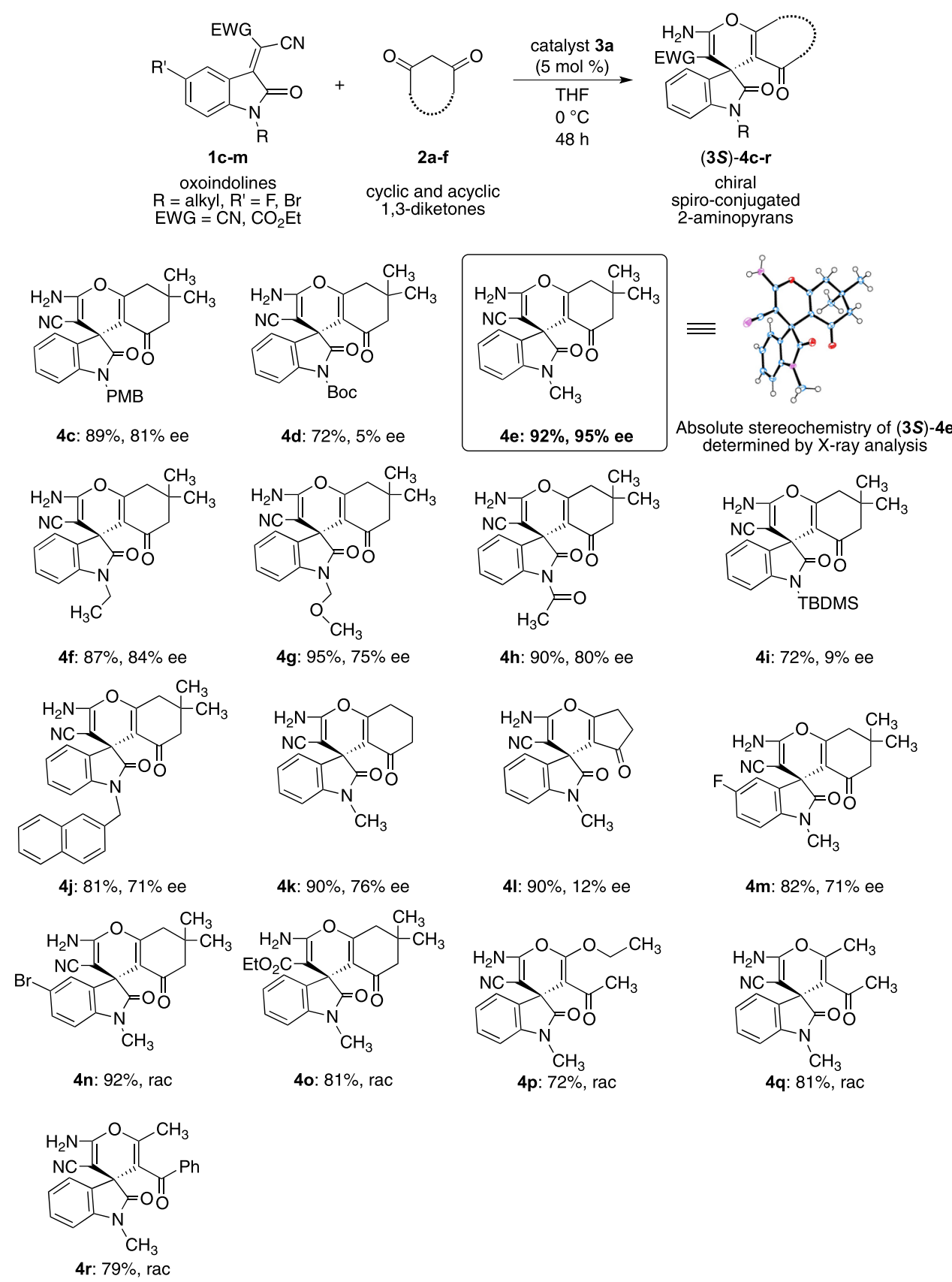

and $2 \mathrm{a}$ using catalyst $3 \mathrm{a}$, the enantioselective reaction course was proposed as follows (Scheme 5). The configuration of 3a might be fixed by the hydrogen-bonding interaction between the hydroxyl hydrogen atom on diphenyl hydroxyl part at side chain and the squaramide carbonyl group. The active methylene proton of dimedone $2 \mathbf{a}$ is abstracted by basic tertiary nitrogen in the pyrrolidine ring of $3 \mathbf{a}$, and the generated enolate species forms hydrogen bond with ammonium site of 3a. Furthermore, the oxoindoline 1e is also fixed to catalyst $\mathbf{3 a}$ through two hydrogen-bonding interactions of cyano groups on $2 \mathrm{a}$ with two amino hydrogen atoms of the squaramide part of the catalyst. Among the two proposed transition states Ts-I and Ts-II, the Michael addition might proceed through Ts-II that has less steric interactions between the substrate and enolate species than those of Ts-I that has larger steric interactions between $\mathbf{1 e}$ and enolate species. Thus, enolate of dimedone $\mathbf{2 a}$ attacks the electrondeficient olefin site of oxoindoline 1e from the side below ( $s i$ face) to afford the chiral Michael adduct $\mathbf{X}$. Furthermore, subsequent intramolecular cyclization leads to the formation of intermediate Y. Finally, tautomerization of 2-iminopyran $\mathbf{Y}$ might afford the formation of (3S)-4e as the major enantiomer.

\section{CONCLUSIONS}

We have demonstrated the first successful enantioselective domino Michael addition/cyclization reaction of cyclic 1,3diketones using our new hybrid-type squaramide-fused amino alcohol (SFAA) organocatalysts $3 \mathbf{a}-\mathbf{e}$ containing both the Brønsted basic site and hydrogen-bonding sites. In the used SFAA catalysts, the catalyst $3 a$ especially showed excellent catalytic activity in the reaction of oxoindolines $\mathbf{1 a}-\mathbf{m}$ with $\mathbf{2 a}-\mathbf{f}$ to afford the quaternary stereogenic chiral spiro- 
Scheme 5. Plausible Reaction Course for Domino Michael Addition/Cyclization Reaction of 1e with 2a Using Catalyst 3a

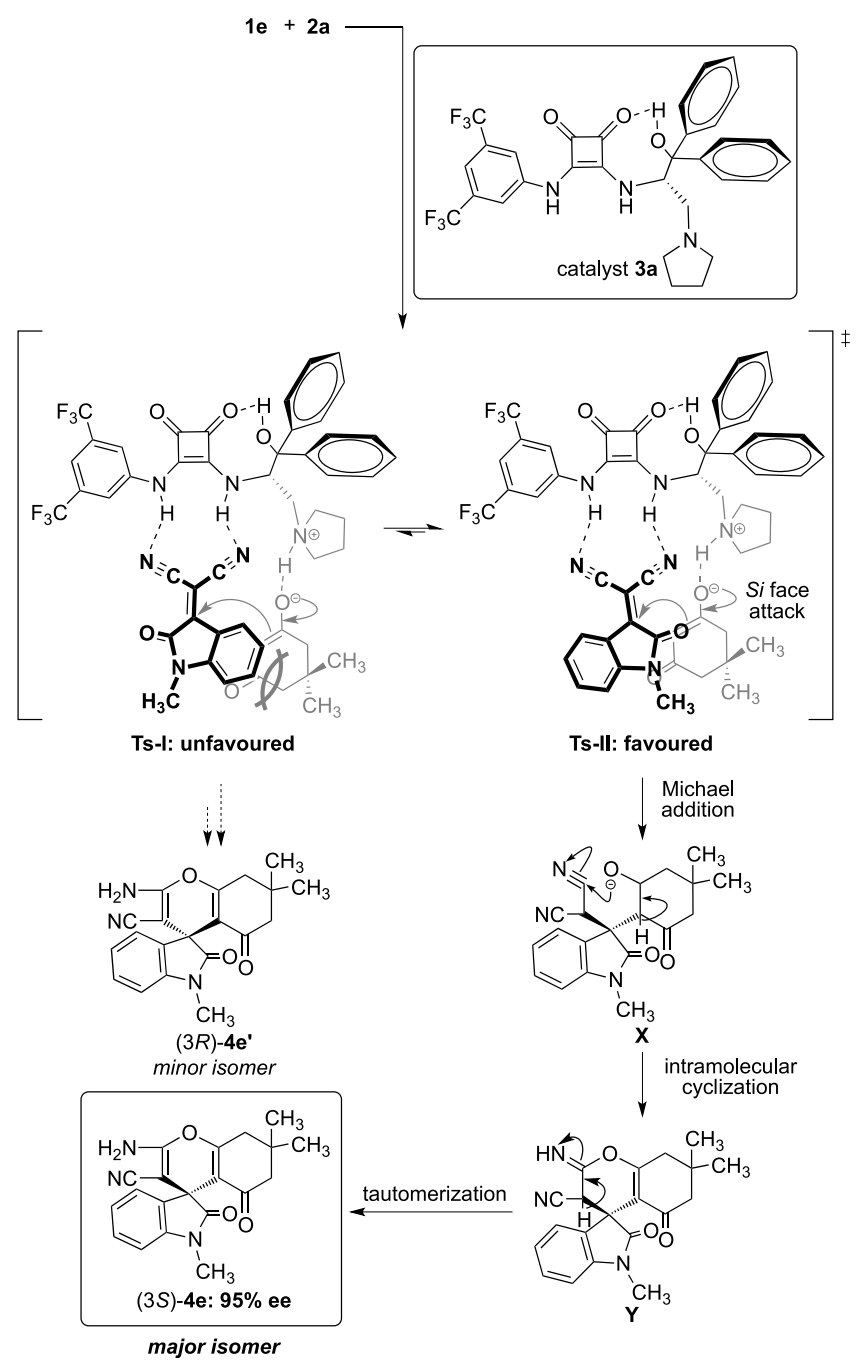

conjugated oxindoles with 2-aminopyrans fusing carboheterocyclic ring systems $\mathbf{4 a}-\mathbf{r}$ in excellent chemical yields (up to 98\%) with satisfactory-to-excellent enantioselectivities (up to $95 \%$ ee). The obtained chiral spiro-conjugated oxindoles $4 \mathbf{a}-\mathbf{r}$ bearing quaternary stereogenic chiral carbon center may work as efficient synthetic intermediates for the synthesis of chiral biologically active compounds and for drug discovery.

\section{EXPERIMENTAL SECTION}

General Information. All reagents and solvents used in this work were bought from commercial channels and used directly. Oxoindolines $\mathbf{1 a}-\mathbf{m}$ were prepared according to the literature procedure. ${ }^{10}$ All reactions were placed under argon atmosphere in flame-dried $4 \mathrm{~mL}$ sample vials inserted with magnetic beads. Thin-layer chromatography (TLC) was performed on Merck silica gel $60 \mathrm{~F}_{254}$ plates, and the analytes were identified under UV light. Flash column chromatography was performed using silica gel pore size $60 \mathrm{~N}(40-100 \mu \mathrm{m})$. Melting points were recorded with a micro-melting-point apparatus. IR spectra were recorded with a JASCO 4100 Fourier transform infrared spectrophotometer. ${ }^{1} \mathrm{H}$ and ${ }^{13} \mathrm{C}$ NMR spectroscopic data were recorded using JEOL JNM-
ECA500 instrument with tetramethylsilane as the internal standard. X-ray diffraction data of $4 \mathrm{e}$ were collected at $93 \mathrm{~K}$ on a Rigaku R-AXIS RAPID diffractometer using multilayer mirror monochromated $\mathrm{Cu} \mathrm{K} \alpha$ radiation. HPLC data were collected using TOSOH instrument equipped with (UV-8020, DP-8020, and SD-8022) detectors using CHIRALCEL OD-H and CHIRALPAK AD-H columns. Optical rotations were recorded using a JASCO DIP-360 digital polarimeter. Highresolution mass spectrometry (HRMS) data were collected by electron impact (EI) and fast atom bombardment (FAB) modes using Hitachi RMG-GMG and JEOL JNX-DX303 sector instruments.

General Procedure for the Synthesis of Compounds $(4 \mathbf{a}-\mathbf{r})$. To a $4 \mathrm{~mL}$ sample vial containing 1,3-diketones $\mathbf{2 a - f}$ $(0.1 \mathrm{mmol})$ and catalyst $3 \mathrm{a}(5 \mathrm{~mol} \%)$ was added anhydrous THF $(1.0 \mathrm{~mL})$. The reaction mixture was allowed to stir at 0 ${ }^{\circ} \mathrm{C}$ for $1 \mathrm{~h}$, followed by addition of 3-dicyano-2-oxoindolines $1 \mathrm{a}-\mathbf{j}(0.1 \mathrm{mmol})$ at the same temperature. The reaction mixture was allowed to be stirred at the same temperature for $48 \mathrm{~h}$. After completion of reaction, indicated by TLC, the residue was purified by using flash column chromatography (ethyl acetate/hexane, 4:6). The enantiomeric excess was determined by chiral HPLC using CHIRALPAK AD-H or CHIRALCEL OD-H columns.

(3S)-2-Amino-1-benzyl-7,7-dimethyl-2,5-doxotetrahydrospiro(chromene-4,3-indoline)-3-carbonitrile (4b). White solid. $92 \mathrm{mg}, 98 \%$ yield. m.p. $250-251{ }^{\circ} \mathrm{C}$. $[\alpha]_{\mathrm{D}}{ }^{24}=$ $-22(c=0.18, \mathrm{MeOH})$. IR (neat): $\mathrm{cm}^{-1}=2962,2189,1706$, 1632, 1492, 1470. ${ }^{1} \mathrm{H}$ NMR (500 MHz, dimethyl sulfoxide (DMSO) $\left.-d_{6}, \mathrm{ppm}\right): \delta 7.55(\mathrm{~d}, J=7.00 \mathrm{~Hz}, 2 \mathrm{H}), 7.40-7.30$ $(\mathrm{m}, 5 \mathrm{H}), 7.18(\mathrm{t}, J=7.50 \mathrm{~Hz}, 1 \mathrm{H}), 7.02(\mathrm{t}, J=8.00 \mathrm{~Hz}, 1 \mathrm{H})$, $6.74(\mathrm{~d}, J=8.00 \mathrm{~Hz}, 1 \mathrm{H}), 4.96(\mathrm{q}, J=16.50,29.50 \mathrm{~Hz}, 2 \mathrm{H})$, $2.66(\mathrm{q}, J=17.50,25.00 \mathrm{~Hz}, 2 \mathrm{H}), 2.27(\mathrm{~d}, J=16.50 \mathrm{~Hz}, 1 \mathrm{H})$, $2.18(\mathrm{~d}, J=16.50 \mathrm{~Hz}, 1 \mathrm{H}), 1.10(\mathrm{~s}, 3 \mathrm{H}), 1.07(\mathrm{~s}, 3 \mathrm{H}) \mathrm{ppm}$. ${ }^{13} \mathrm{C}$ NMR (125 MHz, DMSO- $\left.d_{6}, \mathrm{ppm}\right): 195.2,176.8,164.6$, 159.0, 142.6, 136.2, 133.6, 128.48, 128.40, 127.2, 127.1, 123.0, 122.7, 117.5, 110.7, 109.0, 57.2, 50.0, 46.6, 43.4, 32.0, 27.7, 27.12. MS (EI): $m / z=425[\mathrm{M}]^{+}$, HRMS (EI): calcd for $\mathrm{C}_{26} \mathrm{H}_{23} \mathrm{~N}_{3} \mathrm{O}_{3} \mathrm{~m} / z$ 425.1748; found: 425.1745 . The enantiomeric excess was determined by chiral HPLC; CHIRALPAK $\mathrm{AD}-\mathrm{H}$ column (solvent system 80:20, hexane/isopropyl alcohol (IPA); flow rate, $1.0 \mathrm{~mL} / \mathrm{min}$; temp, $25^{\circ} \mathrm{C}$; detection $\mathrm{UV}, 254 \mathrm{~nm}$; retention time, $32.02 \mathrm{~min}$ (major) and $41.46 \mathrm{~min}$ (minor), ee $=83 \%$ ).

(3S)-2-Amino-1-(4-methoxybenzyl)-7,7-dimethyl-2,5doxo-tetrahydrospiro(chromene-4,3-indoline)-3-carbonitrile (4c). Brown solid. $70 \mathrm{mg}, 89 \%$ yield. m.p. $147-149{ }^{\circ} \mathrm{C}$. $[\alpha]_{\mathrm{D}}{ }^{24}$ $=-21(c=0.18, \mathrm{MeOH})$. IR (neat) $\mathrm{cm}^{-1}: 2972,2189,1707$, 1470, 1370. ${ }^{1} \mathrm{H}$ NMR (500 MHz, DMSO- $\left.d_{6}, \mathrm{ppm}\right): \delta 7.41$ (d, $J=8.50 \mathrm{~Hz}, 2 \mathrm{H}), 7.33(\mathrm{~s}, 2 \mathrm{H}), 7.18-7.06(\mathrm{~m}, 2 \mathrm{H}), 6.94(\mathrm{t}, J=$ $10.00 \mathrm{~Hz}, 1 \mathrm{H}), 6.86(\mathrm{~d}, J=5.00 \mathrm{~Hz}, 2 \mathrm{H}), 6.69(\mathrm{~d}, J=8.00 \mathrm{~Hz}$, $1 \mathrm{H}), 4.83(\mathrm{q}, J=20.00,23.50 \mathrm{~Hz}, 2 \mathrm{H}), 3.71(\mathrm{~s}, 3 \mathrm{H}), 2.60(\mathrm{q}, J$ $=17.50,29.00 \mathrm{~Hz}, 2 \mathrm{H}), 2.15(\mathrm{dd}, J=16.00,28.00 \mathrm{~Hz}, 2 \mathrm{H})$, $1.04(\mathrm{~s}, 3 \mathrm{H}), 1.00(\mathrm{~s}, 3 \mathrm{H}) .{ }^{13} \mathrm{C}$ NMR $\left(125 \mathrm{MHz}, \mathrm{DMSO}-d_{6}\right.$, ppm): 195.0, 176.6, 164.5, 158.9, 158.4, 142.6, 133.6, 128.9, $128.5,128.2,122.9,122.5,117.4,113.7,110.6,109.0,57.2$, 55.0, 49.9, 46.5, 42.7, 32.0, 27.6, 27.0. MS (EI): $m / z=455$ $[\mathrm{M}]^{+}$, HRMS (EI): calcd for $\mathrm{C}_{27} \mathrm{H}_{25} \mathrm{~N}_{3} \mathrm{O}_{3} \mathrm{~m} / z$ 455.1834; found: 455.1838 . The enantiomeric excess was determined by chiral HPLC; CHIRALPAK AD-H column (solvent system 80:20, hexane/IPA; flow rate, $1.0 \mathrm{~mL} / \mathrm{min}$; temp, $25{ }^{\circ} \mathrm{C}$; detection UV, $254 \mathrm{~nm}$; retention time, $48.74 \mathrm{~min}$ (major) and $92.45 \min$ (minor), ee $=81 \%$ ). 
(3S)-2-Amino-1-(tert-butyloxy)-7,7-dimethyl-2,5-doxotetrahydrospiro(chromene-4,3-indoline)-3-carbonitrile (4d). Pale yellow solid. $57 \mathrm{mg}, 72 \%$ yield. m.p. $135-136{ }^{\circ} \mathrm{C} .[\alpha]_{\mathrm{D}}{ }^{24}$ $=-10(c=0.18, \mathrm{MeOH})$. IR (neat): $\mathrm{cm}^{-1}=3309,3179,2189$, 1720, 1715, 1610, 1407, 1309. ${ }^{1} \mathrm{H}$ NMR (500 MHz, DMSO$\left.d_{6}, \mathrm{ppm}\right): \delta 7.87(\mathrm{~d}, J=8.00 \mathrm{~Hz}, 1 \mathrm{H}), 7.30(\mathrm{t}, J=10.00 \mathrm{~Hz}$, $1 \mathrm{H}), 7.12(\mathrm{t}, J=7.50 \mathrm{~Hz}, 1 \mathrm{H}), 7.02(\mathrm{~d}, J=6.50 \mathrm{~Hz}, 1 \mathrm{H}), 4.99$ (s, $2 \mathrm{H}), 2.56-2.46(\mathrm{~m}, 2 \mathrm{H}), 2.23-2.13(\mathrm{~m}, 2 \mathrm{H}), 1.65(\mathrm{~s}$, $12 \mathrm{H}), 1.11(\mathrm{~s}, 3 \mathrm{H}), 1.06(\mathrm{~s}, 3 \mathrm{H}) .{ }^{13} \mathrm{C}$ NMR $(125 \mathrm{MHz}$, DMSO- $\left.d_{6}, \mathrm{ppm}\right): 195.0,175.5,163.9,158.3,149.1,139.8$, 131.4, 129.4, 125.0, 123.2, 116.3, 115.5, 112.2, 84.6, 50.4, 40.9, 32.4, 28.6, 28.3, 27.9. MS (FAB): $m / z=436[\mathrm{M}]^{+}$, HRMS (FAB): calcd for $\mathrm{C}_{24} \mathrm{H}_{26} \mathrm{~N}_{3} \mathrm{O}_{5} \mathrm{~m} / z$ 436.1845; found: 436.1863 . The enantiomeric excess was determined by chiral HPLC; CHIRALPAK AD-H column (solvent system 80:20, hexane/ IPA; flow rate, $1.0 \mathrm{~mL} / \mathrm{min}$; temp, $25{ }^{\circ} \mathrm{C}$; detection UV, 254 $\mathrm{nm}$; retention time, $47.78 \mathrm{~min}$ (major) and $53.24 \mathrm{~min}$ (minor), ee $=5 \%)$.

(3S)-2-Amino-1-methyl-7,7-dimethyl-2,5-doxotetrahydrospiro(chromene-4,3-indoline)-3-carbonitrile (4e). White solid. $86 \mathrm{mg}, 92 \%$ yield. m.p. $195-196{ }^{\circ} \mathrm{C}$. $[\alpha]_{\mathrm{D}}{ }^{24}=$ $-23(c=0.18, \mathrm{MeOH})$. IR (neat): $\mathrm{cm}^{-1}=3308,3176,2189$, $1720,1715,1612,1432,1402 .{ }^{1} \mathrm{H}$ NMR (500 MHz, DMSO$\left.d_{6}, \mathrm{ppm}\right): \delta 7.29(\mathrm{~s}, 1 \mathrm{H}), 7.25(\mathrm{t}, J=8.00 \mathrm{~Hz}, 1 \mathrm{H}), 7.04(\mathrm{~d}, J=$ $7.50 \mathrm{~Hz}, 1 \mathrm{H}), 7.00-6.96(\mathrm{~m}, 2 \mathrm{H}), 3.12(\mathrm{~s}, 3 \mathrm{H}), 2.56(\mathrm{~d}, J=$ $4.00 \mathrm{~Hz}, 2 \mathrm{H}), 2.11(\mathrm{q}, J=16.00,32.50 \mathrm{~Hz}, 2 \mathrm{H}), 1.02(\mathrm{~s}, 3 \mathrm{H})$, $0.98(\mathrm{~s}, 3 \mathrm{H}) .{ }^{13} \mathrm{C}$ NMR $\left(125 \mathrm{MHz}, \mathrm{DMSO}-d_{6}, \mathrm{ppm}\right): 194.9$, $176.6,164.3,158.9,143.5,137.4,133.5,128.9,128.2,125.3$, 122.8, 122.4, 117.2, 110.7, 108.2, 57.0, 49.9, 32.0, 27.5, 27.0, 26.4, 21.1. MS (EI): $m / z=349[\mathrm{M}]^{+}$, HRMS (FAB): calcd for $\mathrm{C}_{20} \mathrm{H}_{19} \mathrm{~N}_{3} \mathrm{O}_{3} \mathrm{~m} / z$ 349.3814; found: 349.3820 . The enantiomeric excess was determined by chiral HPLC; CHIRALCEL OD-H column (solvent system 80:20, hexane/IPA; flow rate, $0.5 \mathrm{~mL} / \mathrm{min}$; temp, $25^{\circ} \mathrm{C}$; detection UV, $254 \mathrm{~nm}$; retention time, $95.54 \mathrm{~min}$ (major) and $48.69 \mathrm{~min}$ (minor), ee $=95 \%$ ).

(3S)-2-Amino-1-(ethyl)-7,7-dimethyl-2,5-doxotetrahydrospiro(chromene-4,3-indoline)-3-carbonitrile (4f). White solid. $56 \mathrm{mg}, 87 \%$ yield. m.p. $280{ }^{\circ} \mathrm{C}$. $[\alpha]_{\mathrm{D}}{ }^{12}=-33$ $(c=0.18, \mathrm{DCM})$. IR (neat): $\mathrm{cm}^{-1}=3312,3305,2193,1674$, 1458. ${ }^{1} \mathrm{H}$ NMR (500 MHz, $\left.\mathrm{CDCl}_{3}, \mathrm{ppm}\right): \delta 7.31-7.24(\mathrm{~m}$, $1 \mathrm{H}), 7.08-6.96(\mathrm{~m}, 2 \mathrm{H}), 6.89(\mathrm{~d}, J=8.0 \mathrm{~Hz}, 1 \mathrm{H}), 4.81(\mathrm{~s}$, $2 \mathrm{H}), 3.92-3.76(\mathrm{~m}, 2 \mathrm{H}), 2.63-2.41(\mathrm{~m}, 2 \mathrm{H}), 2.29-2.0(\mathrm{~m}$, $2 \mathrm{H}), 1.39-1.30(\mathrm{~m}, 3 \mathrm{H}), 1.12(\mathrm{~s}, 3 \mathrm{H}), 1.06(\mathrm{~s}, 3 \mathrm{H}) .{ }^{13} \mathrm{C} \mathrm{NMR}$ $\left(125 \mathrm{MHz}, \mathrm{CDCl}_{3}, \mathrm{ppm}\right): \delta 195.0,176.2,163.8,158.4,142.7$, 133.0, 129.2, 123.2, 122.9, 116.3, 111.9, 108.8, 62.1, 50.6, 41.0, 35.4, 32.4, 28.7, 27.7, 12.2. MS (EI): $\mathrm{m} / z=363[\mathrm{M}]^{+}$, HRMS (EI): calcd for $\mathrm{C}_{21} \mathrm{H}_{21} \mathrm{~N}_{3} \mathrm{O}_{3} \mathrm{~m} / z$ 363.1511; found: 363.1585 . The enantiomeric excess was determined by chiral HPLC; CHIRALPAK AD-H column (solvent system 80:20, hexane/ IPA; flow rate, $1.0 \mathrm{~mL} / \mathrm{min}$; temp, $25{ }^{\circ} \mathrm{C}$; detection UV, 254 $\mathrm{nm}$; retention time, $15.23 \mathrm{~min}$ (major) and $35.11 \mathrm{~min}$ (minor), ee $=83 \%)$.

(3S)-2-Amino-1-(monomethoxymethyl)-7,7-dimethyl-2,5doxo-tetrahydrospiro(chromene-4,3-indoline)-3-carbonitrile (4g). White solid. $49 \mathrm{mg}, 95 \%$ yield. m.p. $109{ }^{\circ} \mathrm{C} .[\alpha]_{\mathrm{D}}{ }^{12}=$ $-105\left(c=0.12\right.$, DCM). IR (neat): $\mathrm{cm}^{-1}=3402,3317,2938$, 2182, 1711, 1684. ${ }^{1} \mathrm{H}$ NMR $\left(500 \mathrm{MHz}, \mathrm{CDCl}_{3}, \mathrm{ppm}\right): \delta 7.32-$ $7.25(\mathrm{~m}, 1 \mathrm{H}), 7.14-7.00(\mathrm{~m}, 3 \mathrm{H}), 5.26-5.16(\mathrm{~m}, 2 \mathrm{H}), 4.92$ $(\mathrm{s}, 2 \mathrm{H}), 3.46(\mathrm{~s}, 3 \mathrm{H}), 2.62-2.42(\mathrm{~m}, 2 \mathrm{H}), 2.28-2.09(\mathrm{~m}, 2 \mathrm{H})$, $1.12(\mathrm{~s}, 3 \mathrm{H}), 1.07$ (s, 3H). ${ }^{13} \mathrm{C} \mathrm{NMR}\left(125 \mathrm{MHz} \mathrm{CDCl}_{3}\right.$, ppm): $\delta$ 195.17, 177.32, 164.00, 158.41, 142.00, 132.25, 129.41, 123.66, 123.18, 116.52, 111.86, 110.07, 72.29, 61.71, $60.59,56.63,50.55,47.34,41.01,32.41,28.68,27.74,21.24$,
14.34. MS (EI): $m / z=379[\mathrm{M}]^{+}$, HRMS (EI): calcd for $\mathrm{C}_{21} \mathrm{H}_{21} \mathrm{~N}_{3} \mathrm{O}_{4} \mathrm{~m} / z$ 379.1512; found: 379.1537. The enantiomeric excess was determined by chiral HPLC; CHIRALPAK $\mathrm{AD}-\mathrm{H}$ column (solvent system 80:20, hexane/IPA; flow rate, $1.0 \mathrm{~mL} / \mathrm{min}$; temp, $25{ }^{\circ} \mathrm{C}$; detection $\mathrm{UV}, 254 \mathrm{~nm}$; retention time, $20.7 \mathrm{~min}$ (major) and $31.48 \mathrm{~min}$ (minor), ee $=75 \%$ ).

(3S)-2-Amino-1-(acetyl)-7,7-dimethyl-2,5-doxotetrahydrospiro(chromene-4,3-indoline)-3-carbonitrile (4h). White solid. $59 \mathrm{mg}, 90 \%$ yield. m.p. $242{ }^{\circ} \mathrm{C}$. $[\alpha]_{\mathrm{D}}{ }^{14}=-99(c=$ $0.15, \mathrm{DCM})$. IR (neat): $\mathrm{cm}^{-1}=3379,3305,2939,2200,1712$, $1619,1472 .{ }^{1} \mathrm{H}$ NMR $\left(500 \mathrm{MHz}, \mathrm{CDCl}_{3}, \mathrm{ppm}\right): \delta 8.26(\mathrm{~d}, J=$ $8.6 \mathrm{~Hz}, 1 \mathrm{H}), 7.33(\mathrm{t}, J=7.4 \mathrm{~Hz}, 1 \mathrm{H}), 7.17(\mathrm{t}, J=7.7 \mathrm{~Hz}, 1 \mathrm{H})$, $7.04(\mathrm{~d}, J=7.4 \mathrm{~Hz}, 1 \mathrm{H}), 4.97(\mathrm{~s}, 2 \mathrm{H}), 2.69(\mathrm{~s}, 3 \mathrm{H}), 2.60-2.45$ $(\mathrm{m}, 2 \mathrm{H}), 2.35-2.11(\mathrm{~m}, 3 \mathrm{H}), 1.13(\mathrm{~s}, 3 \mathrm{H}), 1.07(\mathrm{~s}, 3 \mathrm{H}) .{ }^{13} \mathrm{C}$ NMR (125 MHz, $\left.\mathrm{CDCl}_{3}, \mathrm{ppm}\right): \delta 195.2,177.7,171.0,164.0$, $158.2,140.0,131.5,129.6,125.7,123.0,116.8,116.1,112.2$, 68.7, 61.7, 53.6, 50.3, 47.6, 40.9, 32.5, 28.5, 27.8, 26.7, 22.3. MS (EI): $m / z=377[\mathrm{M}]^{+}$, HRMS (EI): calcd for $\mathrm{C}_{21} \mathrm{H}_{19} \mathrm{~N}_{3} \mathrm{O}_{4}$ $\mathrm{m} / z$ 377.1321; found: 377.1373. The enantiomeric excess was determined by chiral HPLC; CHIRALPAK AD-H column (solvent system 80:20, hexane/IPA; flow rate, $1.0 \mathrm{~mL} / \mathrm{min}$; temp, $25{ }^{\circ} \mathrm{C}$; detection UV, $254 \mathrm{~nm}$; retention time, $37.09 \mathrm{~min}$ (major) and $28.67 \mathrm{~min}$ (minor), ee $=80 \%$ ).

(3S)-2-Amino-1-(tert-butyldimethylsilyl)-7,7-dimethyl-2,5doxo-tetrahydrospiro(chromene-4,3-indoline)-3-carbonitrile (4i). Yellow solid. $32 \mathrm{mg}, 72 \%$ yield. m.p. $119^{\circ} \mathrm{C}$. $[\alpha]_{\mathrm{D}}{ }^{14}=-18$ $(c=0.21, \mathrm{DCM})$. IR (neat): $\mathrm{cm}^{-1}=3345,3309,2829,2215$, $1725,1470,1719,1677 .{ }^{1} \mathrm{H}$ NMR (500 MHz, $\left.\mathrm{CDCl}_{3}, \mathrm{ppm}\right): \delta$ $7.26(\mathrm{tt}, J=8.7,3.4 \mathrm{~Hz}, 1 \mathrm{H}), 7.06-7.00(\mathrm{~m}, 1 \mathrm{H}), 7.00-6.91$ $(\mathrm{m}, 2 \mathrm{H}), 4.69(\mathrm{~d}, J=10.3 \mathrm{~Hz}, 2 \mathrm{H}), 2.58-2.40(\mathrm{~m}, 2 \mathrm{H}), 2.29-$ $2.09(\mathrm{~m}, 2 \mathrm{H}), 1.12(\mathrm{~s}, 3 \mathrm{H}), 1.07(\mathrm{~s}, 12 \mathrm{H}), 0.56(\mathrm{~s}, 3 \mathrm{H}), 0.52$ (s, 3H). ${ }^{13} \mathrm{C}$ NMR (125 MHz, $\left.\mathrm{CDCl}_{3}, \mathrm{ppm}\right): \delta$ 194.1, 183.7, $163.5,157.8,146.1,134.9,128.7,123.2,122.5,116.3,113.1$, $112.4,50.5,40.9,32.3,28.8,27.5,26.4,19.9,-3.2,-3.6 . \mathrm{MS}$ (EI): $m / z=449[\mathrm{M}]^{+}$, HRMS (EI): calcd for $\mathrm{C}_{25} \mathrm{H}_{31} \mathrm{~N}_{3} \mathrm{O}_{3} \mathrm{Si}$ $m / z$ 449.2145; found: 449.2137. The enantiomeric excess was determined by chiral HPLC; CHIRALPAK AD-H column (solvent system 80:20, hexane/IPA; flow rate, $1.0 \mathrm{~mL} / \mathrm{min}$; temp, $25{ }^{\circ} \mathrm{C}$; detection UV, $254 \mathrm{~nm}$; retention time, $4.2 \mathrm{~min}$ (major) and $5.99 \mathrm{~min}$ (minor), ee $=9 \%$ ).

(3S)-2-Amino-1-(methylenenaphthyl)-7,7-dimethyl-2,5doxo-tetrahydrospiro(chromene-4,3-indoline)-3-carbonitrile (4j). White solid. $42 \mathrm{mg}, 81 \%$ yield. m.p. $188-190^{\circ} \mathrm{C}$. $[\alpha]_{\mathrm{D}}{ }^{24}=$ $-11\left(c=0.18\right.$, solvent). IR (neat): $\mathrm{cm}^{-1}=3395,3196,2996$, 2189, 1782, 1676, 1610. ${ }^{1} \mathrm{H}$ NMR (500 MHz, DMSO- $d_{6}$, ppm): $\delta 8.03(\mathrm{~s}, 1 \mathrm{H}), 7.90-7.87(\mathrm{~m}, 2 \mathrm{H}), 7.79-7.77(\mathrm{~m}, 1 \mathrm{H})$, $7.61(\mathrm{~d}, J=8.50 \mathrm{~Hz}, 1 \mathrm{H}), 7.51-7.42(\mathrm{~m}, 2 \mathrm{H}), 7.38(\mathrm{~s}, 2 \mathrm{H})$, $7.36(\mathrm{~s}, 1 \mathrm{H}), 7.10(\mathrm{t}, J=7.50 \mathrm{~Hz}, 2 \mathrm{H}), 6.96(\mathrm{t}, J=7.50 \mathrm{~Hz}$, $1 \mathrm{H}), 6.74(\mathrm{~d}, J=8.00 \mathrm{~Hz}, 1 \mathrm{H}), 5.08(\mathrm{dd}, J=16.50,68.00 \mathrm{~Hz}$, $2 \mathrm{H}), 2.62$ (q, $J=17.50,28.00 \mathrm{~Hz}, 2 \mathrm{H}), 2.19$ (dd, $J=16.00$, $41.00 \mathrm{~Hz}, 2 \mathrm{H}), 1.06$ (s, 3H), 1.02 (s, 3H). ${ }^{13} \mathrm{C}$ NMR (125 $\left.\mathrm{MHz}, \mathrm{DMSO}-d_{6}, \mathrm{ppm}\right): 195.1,176.8,164.6,159.0,142.6$, $133.7,133.6,132.9,132.2,128.3,128.0,127.6,127.5,126.2$, $125.8,125.5,125.2,123.0,122.6,110.7,108.9,57.1,50.0,46.7$, 43.4, 32.0, 27.6, 27.0. MS (EI): $m / z=475[\mathrm{M}]^{+}$, HRMS (FAB): calcd for $\mathrm{C}_{30} \mathrm{H}_{25} \mathrm{~N}_{3} \mathrm{O}_{3} \mathrm{~m} / z$ 475.1823; found: 475.1894 . The enantiomeric excess was determined by chiral HPLC; CHIRALCEL OD-H column (solvent system 80:20, hexane/ IPA; flow rate, $1.0 \mathrm{~mL} / \mathrm{min}$; temp, $25{ }^{\circ} \mathrm{C}$; detection UV, 254 $\mathrm{nm}$; retention time, $45.82 \mathrm{~min}$ (major) and $66.26 \mathrm{~min}$ (minor), ee $=71 \%)$.

(3S)-2-Amino-1-methyl-2,5-doxo-tetrahydrospiro(chromene-4,3-indoline)-3-carbonitrile (4k). White solid. 68 
mg, 90\% yield. m.p. $267-268{ }^{\circ} \mathrm{C} .[\alpha]_{\mathrm{D}}{ }^{24}=-130(c=0.1$, DCM). IR (neat): $\mathrm{cm}^{-1}=3302,2187,1723,1671,1629,1293$. ${ }^{1} \mathrm{H}$ NMR (500 MHz, DMSO- $\left.d_{6}, \mathrm{ppm}\right): \delta 7.30-7.22(\mathrm{~m}, 3 \mathrm{H})$, 7.08-7.05 (m, 1H), 7.00-6.95 (m, 2H), 3.12 (s, 3H), 2.70$2.61(\mathrm{~m}, 2 \mathrm{H}), 2.25-2.14(\mathrm{~m}, 2 \mathrm{H}), 1.936-1.88(\mathrm{~m}, 2 \mathrm{H}) .{ }^{13} \mathrm{C}$ NMR (125 MHz, DMSO- $\left.d_{6}, \mathrm{ppm}\right): \delta$ 195.2, 176.7, 166.3, $158.8,143.5,133.7,128.4,123.0,122.5,117.3,111.8,108.2$, 57.0, 46.6, 36.4, 26.8, 26.4, 19.8. MS (EI): $m / z=321[\mathrm{M}]^{+}$, HRMS (EI): calcd for $\mathrm{C}_{18} \mathrm{H}_{15} \mathrm{~N}_{3} \mathrm{O}_{3} \mathrm{~m} / z$ 321.3312; found: 321.1145. The enantiomeric excess was determined by chiral HPLC; CHIRALPAK AD-H column (solvent system 80:20, hexane/IPA; flow rate, $1.0 \mathrm{~mL} / \mathrm{min}$; temp, $25{ }^{\circ} \mathrm{C}$; detection $\mathrm{UV}, 254 \mathrm{~nm}$; retention time, $12.81 \mathrm{~min}$ (major) and $28.44 \mathrm{~min}$ (minor), ee $=76 \%$ ).

(S)-2-Amino-1'-methyl-2',5-dioxo-6,7-dihydro-5H-spiro[cyclopenta-pyran-4,3'-indoline]-3-carbonitrile (4I). White solid. $31 \mathrm{mg}$, $90 \%$ yield. m.p. $288{ }^{\circ} \mathrm{C}$. $[\alpha]_{\mathrm{D}}{ }^{14}=-33(c=$ $0.16, \mathrm{DCM})$. IR (neat): $\mathrm{cm}^{-1}=3345,3216,2945,2200,1723$, 1678, 1478. ${ }^{1} \mathrm{H}$ NMR (500 MHz, DMSO-d 6 , ppm): $\delta 7.12(\mathrm{~s}$, $2 \mathrm{H}), 6.92-6.78(\mathrm{~m}, 1 \mathrm{H}), 6.78-6.64(\mathrm{~m}, 1 \mathrm{H}), 6.64-6.47(\mathrm{~m}$, $2 \mathrm{H}), 2.70(\mathrm{~s}, 3 \mathrm{H}), 2.44-2.29(\mathrm{~m}, 2 \mathrm{H}), 1.96-1.82(\mathrm{~m}, 2 \mathrm{H})$. ${ }^{13} \mathrm{C}$ NMR (125 MHz, DMSO- $\left.d_{6}, \mathrm{ppm}\right): \delta 199.9,177.8,175.2$, $160.8,143.5,131.3,129.1,124.0,122.9,117.5,114.8,108.6$, 67.1, 56.0, 46.3, 33.2, 26.5, 25.2, 25.0. MS (EI): $m / z=307$ $[\mathrm{M}]^{+}$, HRMS (EI): calcd for $\mathrm{C}_{17} \mathrm{H}_{13} \mathrm{~N}_{3} \mathrm{O}_{3} \mathrm{~m} / z$ 307.0917; found: 307.0966. The enantiomeric excess was determined by chiral HPLC; CHIRALPAK AD-H column (solvent system 80:20, hexane/IPA; flow rate, $1.0 \mathrm{~mL} / \mathrm{min}$; temp, $25{ }^{\circ} \mathrm{C}$; detection UV, $254 \mathrm{~nm}$; retention time, $13.15 \mathrm{~min}$ (major) and $21.42 \min$ (minor), ee $=12 \%$ ).

(3S)-2-Amino-5'-fluoro-1',7,7-trimethyl-2',5-dioxo5,6,7,8-tetrahydrospiro[chromene-4,3'-indoline]-3-carbonitrile $(4 \mathrm{~m})$. White solid. $64 \mathrm{mg}, 71 \%$ yield. m.p. $211^{\circ} \mathrm{C} .[\alpha]_{\mathrm{D}}{ }^{24}$ $=-34(c=0.23, \mathrm{DCM})$. IR (neat): $\mathrm{cm}^{-1}=3308,3176,2189$, $1720,1715,1612,1432,1402 .{ }^{1} \mathrm{H}$ NMR $\left(500 \mathrm{MHz}, \mathrm{CD}_{3} \mathrm{OD}\right.$, ppm): $\delta 7.04(\mathrm{td}, J=8.9,2.9 \mathrm{~Hz}, 1 \mathrm{H}), 6.98(\mathrm{q}, J=4.2 \mathrm{~Hz}$, $1 \mathrm{H}), 6.92(\mathrm{dd}, J=7.7,2.6 \mathrm{~Hz}, 1 \mathrm{H}), 3.25$ (s, $3 \mathrm{H}), 2.68-2.55$ (m, 2H), 2.29-2.22 (m, 2H), $1.07(\mathrm{~s}, 6 \mathrm{H}) .{ }^{13} \mathrm{C}$ NMR (125 $\left.\mathrm{MHz}, \mathrm{CD}_{3} \mathrm{OD}, \mathrm{ppm}\right): \delta 197.7,179.5,167.0,162.2,161.1$, $160.2,140.9,117.9,116.0,115.8,112.1,111.9,110.5,51.3$, 41.5, 33.2, 28.4, 27.0. MS (EI): $m / z=367[\mathrm{M}]^{+}$, HRMS (FAB): calcd for $\mathrm{C}_{20} \mathrm{H}_{18} \mathrm{FN}_{3} \mathrm{O}_{3} \mathrm{~m} / z$ 367.1312; found: 367.1336. The enantiomeric excess was determined by chiral HPLC; CHIRALPAK AD-H column (solvent system 80:20, hexane/IPA; flow rate, $1.0 \mathrm{~mL} / \mathrm{min}$; temp, $25{ }^{\circ} \mathrm{C}$; detection $\mathrm{UV}, 254 \mathrm{~nm}$; retention time, $32.51 \mathrm{~min}$ (major) and $29.39 \mathrm{~min}$ (minor), ee $=71 \%$ ).

2-Amino-5'-bromo-1',7,7-trimethyl-2',5-dioxo-5,6,7,8tetrahydrospiro[chromene-4,3'-indoline]-3-carbonitrile (4n). Brown solid. $57 \mathrm{mg}, 92 \%$ yield. m.p. $242{ }^{\circ} \mathrm{C}$. $[\alpha]_{\mathrm{D}}{ }^{24}=-10(c=$ 0.30, $\mathrm{MeOH})$. IR (neat): $\mathrm{cm}^{-1}=3310,3146,2199,1721$, $1715,1612,1432,1402 .{ }^{1} \mathrm{H}$ NMR (500 MHz, $\left.\mathrm{CD}_{3} \mathrm{OD}\right) \delta$ $7.34-7.27(\mathrm{~m}, 1 \mathrm{H}), 7.14-7.08(\mathrm{~m}, 1 \mathrm{H}), 6.99(\mathrm{~d}, J=7.7 \mathrm{~Hz}$, $1 \mathrm{H}), 3.23(\mathrm{~s}, 3 \mathrm{H}), 2.62(\mathrm{q}, J=17.6 \mathrm{~Hz}, 2 \mathrm{H}), 2.27-2.13(\mathrm{~m}$, $2 \mathrm{H}), 1.11(\mathrm{~s}, 3 \mathrm{H}), 1.09(\mathrm{~s}, 3 \mathrm{H}) .{ }^{13} \mathrm{C} \mathrm{NMR}(125 \mathrm{MHz}$, $\left.\mathrm{CD}_{3} \mathrm{OD}, \mathrm{ppm}\right): \delta 197.7,179.3,167.1,161.2,143.7,136.7$, $129.8,129.6,124.5,117.9,111.8,110.8,51.3,41.5,33.2,28.1$, 27.0. MS (EI): $m / z=428[\mathrm{M}]^{+}$, HRMS (FAB): calcd for $\mathrm{C}_{20} \mathrm{H}_{18} \mathrm{BrN}_{3} \mathrm{O}_{3} \mathrm{~m} / z$ 428.0523; found: 428.0592. The enantiomeric excess was determined by chiral HPLC; CHIRALPAK AD-H column (solvent system 80:20, hexane/IPA; flow rate, $1.0 \mathrm{~mL} / \mathrm{min}$; temp, $25{ }^{\circ} \mathrm{C}$; detection $\mathrm{UV}, 254 \mathrm{~nm}$; retention time, $31.27 \mathrm{~min}$ (minor) and $82.45 \mathrm{~min}$ (major), racemate).
Ethyl 2-Amino-1',7,7-trimethyl-2',5-dioxo-5,6,7,8tetrahydrospiro[chromene-4,3'-indoline]-3-carboxylate (4o). White solid. $65 \mathrm{mg}, 81 \%$ yield. m.p. $233{ }^{\circ} \mathrm{C}$. $[\alpha]_{\mathrm{D}}{ }^{24}=-10$ $(c=0.12, \mathrm{MeOH}) . \mathrm{IR}$ (neat) $: \mathrm{cm}^{-1}=3415,3322,3293,2198$, $1725,1674,1483 .{ }^{1} \mathrm{H}$ NMR $\left(500 \mathrm{MHz}, \mathrm{DMSO}-d_{6}, \mathrm{ppm}\right): \delta$ $7.86(\mathrm{~s}, 2 \mathrm{H}), 7.29(\mathrm{~s}, 2 \mathrm{H}), 7.08(\mathrm{~s}, 1 \mathrm{H}), 6.83-6.61(\mathrm{~m}, 2 \mathrm{H})$, $3.03(\mathrm{~s}, 3 \mathrm{H}), 2.53-2.44(\mathrm{~m}, 4 \mathrm{H}), 2.07-1.85(\mathrm{~m}, 2 \mathrm{H}), 0.93(\mathrm{~s}$, $3 \mathrm{H}), 0.86$ (s, 3H), 0.65 (s, 3H). ${ }^{13} \mathrm{C}$ NMR (125 MHz, DMSO$\left.d_{6}, \mathrm{ppm}\right): \delta 194.9,178.3,167.6,162.7,159.3,145.3,135.0$, $128.4,127.6,122.1,121.4,113.0,107.0,75.9,58.9,50.6,46.1$, 31.7, 27.8, 26.7, 26.2, 13.6. MS (EI): $m / z=396[\mathrm{M}]^{+}$, HRMS (EI): calcd for $\mathrm{C}_{22} \mathrm{H}_{24} \mathrm{~N}_{2} \mathrm{O}_{5} \mathrm{~m} / z$ 396.1611; found: 396.1683 . The enantiomeric excess was determined by chiral HPLC; CHIRALPAK AD-H column (solvent system 80:20, hexane/ IPA; flow rate, $1.0 \mathrm{~mL} / \mathrm{min}$; temp, $25{ }^{\circ} \mathrm{C}$; detection UV, 254 $\mathrm{nm}$; retention time, $41.65 \mathrm{~min}$ (major) and $14.95 \mathrm{~min}$ (minor), racemate).

3'-Acetyl-6'-amino-2' -ethoxy-1-methyl-2-oxospiro[indoline-3, $4^{\prime}$-pyran]-5'-carbonitrile (4p). White solid. $31 \mathrm{mg}$, $72 \%$ yield. m.p. $228{ }^{\circ} \mathrm{C}$. $[\alpha]_{\mathrm{D}}{ }^{24}=-22(c=0.11, \mathrm{MeOH})$. IR (neat): $\mathrm{cm}^{-1}=3420,3324,3290,2198,1724,1645,1479 .{ }^{1} \mathrm{H}$ NMR $\left(500 \mathrm{MHz}, \mathrm{CDCl}_{3}, \mathrm{ppm}\right): \delta 7.29(\mathrm{td}, J=7.7,1.2 \mathrm{~Hz}$, $1 \mathrm{H}), 7.15-7.09(\mathrm{~m}, 1 \mathrm{H}), 7.09-7.02(\mathrm{~m}, 1 \mathrm{H}), 6.84(\mathrm{t}, J=6.9$ $\mathrm{Hz}, 1 \mathrm{H}), 4.80(\mathrm{~s}, 2 \mathrm{H}), 3.94-3.68(\mathrm{~m}, 2 \mathrm{H}), 3.25(\mathrm{~s}, 3 \mathrm{H}), 2.40$ $(\mathrm{s}, 3 \mathrm{H}), 0.86(\mathrm{t}, J=7.50 \mathrm{~Hz}, 3 \mathrm{H}) .{ }^{13} \mathrm{C} \mathrm{NMR}(125 \mathrm{MHz}$, $\left.\mathrm{CDCl}_{3}, \mathrm{ppm}\right): \delta 177.4,164.7,159.7,158.5,143.5,133.3,129.3$, $123.6,123.3,116.6,108.3,105.1,60.8,26.7,19.2,13.5$. MS (EI): $m / z=339[\mathrm{M}]^{+}$, HRMS (EI): calcd for $\mathrm{C}_{18} \mathrm{H}_{17} \mathrm{~N}_{3} \mathrm{O}_{4} \mathrm{~m} /$ $z$ 339.1256; found: 339.1224. The enantiomeric excess was determined by chiral HPLC; CHIRALPAK AD-H column (solvent system 80:20, hexane/IPA; flow rate, $1.0 \mathrm{~mL} / \mathrm{min}$; temp, $25{ }^{\circ} \mathrm{C}$; detection UV, $254 \mathrm{~nm}$; retention time, $10.1 \mathrm{~min}$ (minor) and 11.72 min (major), racemate).

3'-Acetyl-6' -amino-1,2' -dimethyl-2-oxospiro [indoline3,4'-pyran]-5'-carbonitrile (4q). White solid. $48 \mathrm{mg}, 81 \%$ yield. m.p. $180{ }^{\circ} \mathrm{C} .[\alpha]_{\mathrm{D}}{ }^{24}=-21(c=0.13, \mathrm{MeOH})$. IR (neat): $\mathrm{cm}^{-1}=3379,3305,2939,2200,1712,1619,1471 .{ }^{1} \mathrm{H}$ NMR $\left(500 \mathrm{MHz}, \mathrm{DMSO}-d_{6}, \mathrm{ppm}\right): \delta 7.26(\mathrm{td}, J=7.7,1.1 \mathrm{~Hz}, 1 \mathrm{H})$, $7.18(\mathrm{~s}, 2 \mathrm{H}), 7.08(\mathrm{dd}, J=7.4,1.1 \mathrm{~Hz}, 1 \mathrm{H}), 7.02-6.95(\mathrm{~m}$, $2 \mathrm{H}), 3.12$ (s, 3H), 2.31 (s, 3H), $2.08(\mathrm{~s}, 3 \mathrm{H}) .{ }^{13} \mathrm{C}$ NMR $(125$ MHz, DMSO- $\left.d_{6}, \mathrm{ppm}\right): \delta 197.3,177.1,159.3,157.0,143.5$, 133.5, 128.7, 123.0, 122.6, 117.5, 114.9, 108.4, 56.4, 49.0, 31.4, 26.4, 19.6. MS (EI): $m / z=309[\mathrm{M}]^{+}$, HRMS (EI): calcd for $\mathrm{C}_{17} \mathrm{H}_{15} \mathrm{~N}_{3} \mathrm{O}_{3} \mathrm{~m} / z$ 309.1112; found: 309.1112. The enantiomeric excess was determined by chiral HPLC; CHIRALPAK $\mathrm{AD}-\mathrm{H}$ column (solvent system 80:20, hexane/IPA; flow rate, $1.0 \mathrm{~mL} / \mathrm{min}$; temp, $25{ }^{\circ} \mathrm{C}$; detection UV, $254 \mathrm{~nm}$; retention time, $13.66 \mathrm{~min}$ (major) and $16.72 \mathrm{~min}$ (minor), racemate).

2'-Amino-5'-benzoyl-1,6'-dimethyl-2-oxospiro[indoline3,4'-pyran]-3'-carbonitrile (4r). White solid. $48 \mathrm{mg}, 79 \%$ yield. m.p. $180{ }^{\circ} \mathrm{C} .[\alpha]_{\mathrm{D}}{ }^{24}=-11(c=0.22, \mathrm{MeOH})$. IR (neat): $\mathrm{cm}^{-1}=3371,3315,2929,2200,1712,1619,1481 .{ }^{1} \mathrm{H}$ NMR $\left(500 \mathrm{MHz}, \mathrm{CD}_{3} \mathrm{OD}, \mathrm{ppm}\right): \delta 7.78-7.62(\mathrm{~m}, 2 \mathrm{H}), 7.56(\mathrm{t}, J=$ $7.4 \mathrm{~Hz}, 1 \mathrm{H}), 7.49-7.28(\mathrm{~m}, 3 \mathrm{H}), 7.24(\mathrm{t}, J=7.7 \mathrm{~Hz}, 1 \mathrm{H}), 6.99$ $(\mathrm{t}, J=7.4 \mathrm{~Hz}, 1 \mathrm{H}), 6.91(\mathrm{~d}, J=8.0 \mathrm{~Hz}, 1 \mathrm{H}), 3.23(\mathrm{~s}, 3 \mathrm{H}), 1.77$ (s, 3H). ${ }^{13} \mathrm{C}$ NMR (125 MHz, $\left.\mathrm{CD}_{3} \mathrm{OD}, \mathrm{ppm}\right): \delta 195.9,162.5$, $156.7,139.9,134.6,130.6,130.2,130.0,125.5,124.6,109.9$, 27.1, 20.0. MS (EI): $m / z=371[\mathrm{M}]^{+}$, HRMS (EI): calcd for $\mathrm{C}_{22} \mathrm{H}_{17} \mathrm{~N}_{3} \mathrm{O}_{3} \mathrm{~m} / z$ 371.2780; found: 371.2783. The enantiomeric excess was determined by chiral HPLC; CHIRALPAK $\mathrm{AD}-\mathrm{H}$ column (solvent system 80:20, hexane/IPA; flow rate, $1.0 \mathrm{~mL} / \mathrm{min}$; temp, $25{ }^{\circ} \mathrm{C}$; detection UV, $254 \mathrm{~nm}$; retention time, $25.46 \mathrm{~min}$ (minor) and $28.12 \mathrm{~min}$ (major), racemate). 


\section{ASSOCIATED CONTENT}

\section{S Supporting Information}

The Supporting Information is available free of charge on the ACS Publications website at DOI: 10.1021/acsomega. 8 b01271.

${ }^{1} \mathrm{H}$ and ${ }^{13} \mathrm{C}$ NMR spectra and HPLC chromatographs (PDF)

X-ray crystallographic data for $4 \mathrm{e}$ (CIF) CCDC 1823802 (CIF)

\section{AUTHOR INFORMATION}

\section{Corresponding Author}

*E-mail: catanaka@mmm.muroran-it.ac.jp. http://www3. muroran-it.ac.jp/hnakano/.

\section{ORCID}

Madhu Chennapuram: 0000-0001-9068-8782

\section{Notes}

The authors declare no competing financial interest.

\section{ACKNOWLEDGMENTS}

We thank the Adaptable \& Seamless Technology Transfer Program through Target-Driven R\&D of the Japan Science and Technology (JST) (AS231Z01382G and AS221Z01186D) for partial financial support of this research.

\section{REFERENCES}

(1) (a) Galliford, C. V.; Scheidt, K. A. Pyrrolidinyl-spirooxindoles Natural Products as Inspiration for the Development of Potential Therapeutic Agents. Angew. Chem., Int. Ed. 2007, 46, 8748-8758. (b) Trost, B. M.; Chunhui, J. Catalytic Enantioselective Construction of All-Carbon Quaternary Stereocenters. Synthesis 2006, 369-396. (c) Marti, C.; Carreira, E. M. Construction of Spiro[pyrrolidine-3,3'oxindoles]-Recent Applications to the Synthesis of Oxindole Alkaloids. Eur. J. Org. Chem. 2003, 2209-2219. (d) Cano, R.; Ramón, D. J.; Yus, M. Transition-Metal-Free $O$-, $S$-, and N-Arylation of Alcohols, Thiols, Amides, Amines, and Related Heterocycles. J. Org. Chem. 2011, 76, 654-660. (e) Bisht, S.; Rani, R.; Peddinti, R. K. Regioselective synthesis of Bicyclic and Polycyclic Systems by Cycloaddition Reactions of Alkenyl $p$-Benzoquinones. J. Org. Chem. 2018, 83, 75-84. (f) Williams, R. M.; Cox, R. J. Paraherquamides, Brevianamides, and Asperparalines: Laboratory Synthesis and Biosynthesis. An Interim Report. Acc. Chem. Res. 2003, 36, 127-139. (g) Kumar, M.; Chauhan, P.; Valkonen, A.; Rissanen, K.; Enders, D. Asymmetric Synthesis of Functionalized Tricyclic Chromanes via an organocatalytic Triple Domino Reaction. Org. Lett. 2017, 19, 30253028.

(2) (a) Tietze, L. F. Domino Reactions in Organic Synthesis. Chem. Rev. 1996, 96, 115-136. (b) Bisht, S.; Peddinti, R. K. FeCl 3 -Mediated domino Reaction of Benzoxazinones with Aroylmethylidene Malonates: Synthesis to Functionalized Pyrrolobenzoxazines. J. Org. Chem. 2017, 82, 13617-13625. (c) Zhang, J.; Yin, G.; Du, Y.; Yang, Z.; Li, Y.; Chen, L. Michael-Michael Addition Reactions Promoted by Secondary Amine-Thiourea: Stereocontrolled constructions of Barbiturate-Fused Tetrahydropyrano Scaffolds and Pyranocoumarins. J. Org. Chem. 2017, 82, 13594-13601. (d) Chauhan, P.; Mahajan, S.; Enders, D. Achieving Molecular Complexity via Stereoselective Multiple Domino Reactions Promoted by a Secondary Amine Organocatalyst. Acc. Chem. Res. 2017, 50, 2809-2821. (e) Chaudhari, P. D.; Hong, B. C.; Lee, G. H. Organocatalytic Enantioselective Michael-Michael-Michael-Aldol Condensation Reactions: Control of Six Streocenters in a quadruple-Cascade Asymmetric Synthesis of Polysubstituted Spirocyclic Oxindoles. Org. Lett. 2017, 19, 61126115.

(3) (a) Bindra, J. S. In The Alkaloids: Chemistry and Physiology; Manske, R. H. F., Ed.; Academic Press: New York, 1973; Vol. 14, pp
83-121. (b) Antonchick, A. P.; Lopez-Tosco, S.; Parga, J.; Sievers, S.; Schuermann, M.; Preut, H.; Susanne, S.; Hans, R.; Sterneckert, J.; Rauh, D.; Waldmann, H. Highly Enantioselective Catalytic Synthesis of Neurite Growth-Promoting Secoyohimbanes. Chem. Biol. 2013, 20, 500-509. (c) Amat, M.; Ramos, C.; Pérez, M.; Molins, E.; Florindo, P.; Santos, M. M. M.; Bosch, J. Enantioselective Formal synthesis of ent-Rhynchophylline and ent-Isorhynchophylline. Chem. Commun. 2013, 49, 1954-1956.

(4) (a) Jossang, A.; Jossang, P.; Hadi, H. A.; Sevenet, T.; Bodo, B. Horsfiline, an oxindole alkaloid from Horsfieldia superba. J. Org. Chem. 1991, 56, 6527-6530. (b) Ban, Y.; Taga, N.; Oishi, T. the synthesis of 3-spirooxindole derivatives: Total syntheses of DL-formosanine, DLisoformosanine, DL-mitraphylline and DL-isomitraphylline. Tetrahedron Lett. 1974, 15, 187-190. (c) Beecham, A. F.; Hart, N. K.; Johns, S. R.; Lamberton, J. A. Stereochemistry of oxindole alkaloids. Uncarines A, B (Formosanine), C (Pteropodine), D (Speciophylline), E (Isopteropodine), and F. Aust. J. Chem. 1968, 21, 491-504.

(5) (a) White, J. D.; Li, Y.; Ihle, D. C. Tandem Intramolecular Photocycloaddition-Retro-Mannich Fragmentation as a route to spiro[pyrrolidine-3-3'-oxindoles]. Total synthesis of $( \pm)$-Coreulescine, $( \pm)$-Horsfiline, $( \pm)$-Elacomine, and $( \pm)$-6-Deoxyelacomine. J. Org. Chem. 2010, 75, 3569-3577. (b) Cui, C. B.; Kakeya, H.; Osada, H. Spirotryprostatin B, a Novel Mammalian Cell Cycle Inhibitor Produced by Aspergillus fumigatus. J. Antibiot. 1996, 49, 832-835. (c) Miyake, F. Y.; Yakushijin, K.; Horne, D. A. Preparation and Synthetic Applications of 2-Halotryptamines: Synthesis of Elacomine and Isoelacomine. Org. Lett. 2004, 6, 711-713. (d) Borschberg, H. R. New Strategies for The Synthesis of Monoterpene indole Alkaloids. Curr. Org. Chem. 2005, 9, 1465-1491.

(6) (a) Kumar, A.; Lohan, P.; Aneja, D. K.; Gupta, G. K.; Kaushik, D.; Prakash, O. Design, synthesis, Computational and Biological Evaluation of Some New Hydrazino Derivatives of DHA and Pyranopyrazoles. Eur. J. Med. Chem. 2012, 50, 81-89. (b) Pellegrini, C.; Weber, M.; Borchbeg, H.-J. Total Synthesis of ( \pm )-Elacomine and (-)-Isoelcacomine, Two Hitherto Unnamed Oxindole Alkaloids from Elaeagnus commutata. Helv. Chim. Acta 1996, 79, 151-168.

(7) Chen, W. B.; Wu, Z. J.; Pei, Q. L.; Cun, L. F.; Zhang, X. M.; Yuan, W. C. Highly Enantioselective Construction of Spiro[4H-pyran3-3'-oxindoles] Through a Domino Knoevenagel/Michael/Cyclization sequence Catalyzed by Cupreine. Org. Lett. 2010, 12, 31323135 .

(8) Birch, A. J.; Russell, R. A. Studies in relation to biosynthesisXLIV: Structural elucidations of brevianamides-B, -C, -D and -F. Tetrahedron 1972, 28, 2999-3008.

(9) (a) Chennapuram, M.; Reddy, U. V. S.; Seki, C.; Okuyama, Y.; Kwon, E.; Uwai, K.; Tokiwa, M.; Takeshita, M.; Nakano, H. HybridType Squaramide-Fused Amino Alcohol Organocatalysts for Enantioselective Nitro-Aldol Reaction of Nitromethane with Isatins. Eur. J. Org. Chem. 2017, 1638-1646. (b) Chennapuram, M.; Reddy, U. V. S.; Seki, C.; Okuyama, Y.; Kwon, E.; Uwai, K.; Tokiwa, M.; Takeshita, M.; Nakano, H. Hybrid-Type Squaramide-Fused Amino Alcohol Organocatalysts for Enantioselective Diels-Alder Reactions of 3-Hydroxy-2-pyridones with Maleimides. Eur. J. Org. Chem. 2017, $4633-4641$.

(10) He, T.; Zeng, Q. Q.; Yang, D. C.; He, Y. H.; Guan, Z. Biocatalytic one-pot three-component synthesis of 3-3'-disubstitued oxindoles and spirooxindole pyrans using $\alpha$-amylase from hog pancreas. RSC Adv. 2015, 5, 37843-37852. 